\title{
Protoariciella uncinata Hartmann-Schröeder, 1962 (Polychaeta, Orbiniidae): a new record for intertidal mussel beds of the Southwestern Atlantic shore affected by sewage effluents*
}

\author{
Protoariciella uncinata Hartmann-Schröeder, 1962 (Polychaeta, Orbiniidae): un nuevo registro \\ para la comunidad de mitílidos intermareales del Atlántico sudoccidental \\ afectada por efluentes cloacales \\ Rodolfo Elias $^{1}$, Eduardo A. Vallarino ${ }^{1}$ and Claudia S. Bremec ${ }^{2}$ \\ * Contribución Científica 112 del Departamento de Ciencias Marinas (UNMdP) y Contribución Científica 1160 del INIDEP. \\ ${ }^{I}$ Departamento de Ciencias Marinas, Universidad Nacional de Mar del Plata, Dean Funes 3350 (7600) Mar del Plata - Argentina. \\ ${ }^{2}$ INIDEP-CONICET, cc 175 (7600) Mar del Plata-Argentina. \\ roelias@mdp.edu.ar
}

Resumen.- La especie Protoariciella uncinata (Polychaeta, Orbiniidae) es mencionada por primera vez para el Atlántico sudoccidental, proveniente de muestreos intermareales realizados en la comunidad del mitílido Brachidontes rodriguezi del área de Mar del Plata, Argentina. La especie ha sido anteriormente citada para bancos de mitílidos de Chile y Perú. El trabajo también brinda información sobre distribución espacial, relación con el gradiente orgánico producido por efluentes cloacales, densidad y otros datos ecológicos.

Palabras clave: Protoaricinae, primer registro, distribución, Océano Atlántico.

\begin{abstract}
Protoariciella uncinata (Polychaeta, Orbiniidae) is mentioned for the first time in southwestern Atlantic shores, from mytilid mussel beds of Brachidontes rodriguezi of the Mar del Plata area, Argentine. The species was formely described for mytilids banks of the Pacific coast of Chile and Peru. The work also provides information about spatial distribution, relationship with sewage organic enrichment, density and other ecological data.

Keywords: Protoaricinae, first mention, distribution, Atlantic Ocean.
\end{abstract}

\section{Introduction}

Mussel beds are effective refuges for several small organisms. In the Southwestern Atlantic shore, the Perna perna community (Jacobi 1987) in southern Brazil, and the Brachidontes rodriguezi community in Uruguay and northern Argentine (Olivier et al. 1966, Penchaszadeh 1973, Scelzo et al. 1996) are examples of this phenomenon. In the latter community, debris and sediments accumulate among byssal filaments (up to 19 $\mathrm{kg} \mathrm{m} \mathrm{m}^{-2}$ in horizontal substrates), being colonized by polychaetes, nemerteans and other invertebrates (Penchaszadeh 1973). These processes increase when patches become older and multilayered.

The identification of the associated polychaetes in the Brachidontes rodriguezi community was incomplete. Recently, in a study of the community structure of B. rodriguezi (Vallarino et al. 1999 ${ }^{1}$ )

\footnotetext{
${ }^{1}$ Vallarino EA, R Elias \& MS Campodonico. 1999. La comunidad intermareal de Brachidontes rodriguezi bajo condiciones de enriquecimiento orgánico por efluentes cloacales. VIII COLACMAR, Trujillo, Perú, vol. II: 893-894.
}

developed in abrassion platforms affected by domestic sewage of the Mar del Plata City $\left(38^{\circ} \mathrm{S}-57^{\circ} \mathrm{W}\right)$, a number of polychaetes were identified (Elias et al. $\left.1999^{2}\right)$. One of them corresponds to Protoariciella uncinata Hartmann-Schröeder (1962a). This is the first mention of the species in waters of the Southwestern Atlantic shore, being formely cited for the Pacific coasts of Peru and Chile.

\section{Material And Methods}

\section{Study area}

The sampling area is an open coast subjected to the littoral current (south to north), with extense sand beaches only interrupted by quarcitic outcrops and

\footnotetext{
2 Elias R, EA Vallarino, CS Bremec \& MC Gravina. 1999. Los poliquetos de la comunidad intermareal como bioindicadores de enriquecimiento orgánico en el Atlántico sudoccidental. VIII COLACMAR, Trujillo, Perú, vol. II: 904-905.
} 
abrassion platforms of caliche (consolidate loees). Biogeographically, the region is a transitional temperate-cold water area, between the subantarctic (Patagonia) and the subtropical region (southern Brazil). Seawater temperature ranges between 8 and $21{ }^{\circ} \mathrm{C}$ and salinity between 33 and 34 PSU. Semidiurnal tides vary between 0,90 to $0,60 \mathrm{~m}$.
Sewage discharges are produced in intertidal abrassion platforms, about $6 \mathrm{~km}$ north to the city, where 5 stations (named $\mathrm{A}$, far, to $\mathrm{E}$, close to the effluent) were randomly sampled with a $78 \mathrm{~cm}^{2}$ corer in two tidal levels (4 sampling units in the upper fringe and 4 in the lower fringe). A control station (X) was sampled in the same way $9 \mathrm{~km}$ north to the effluent in a similar abrassion platform (Santa Elena Formation) .

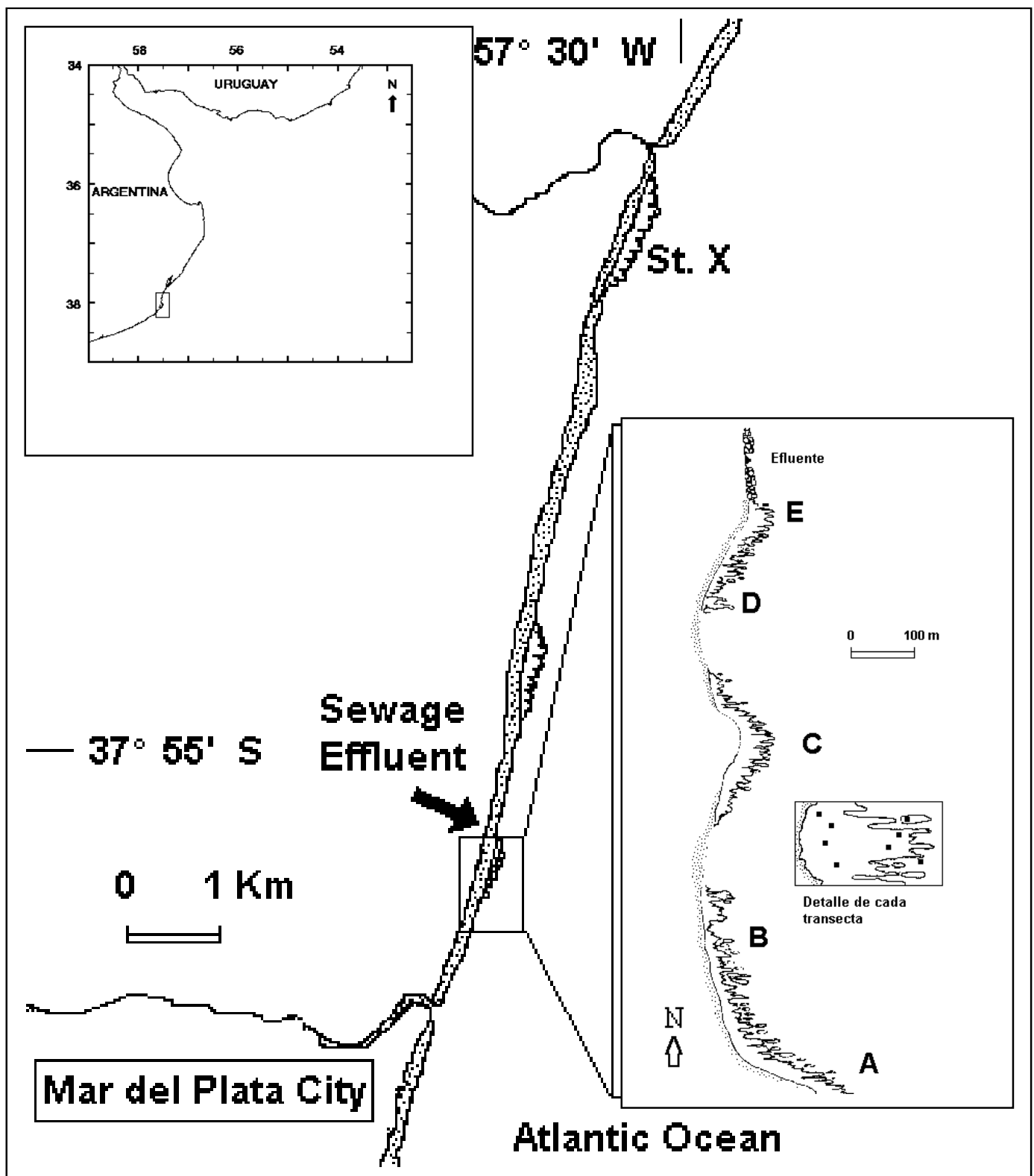

Figure 1

Sampling design in the intertidal mussel beds of the mytilid Brachidontes rodriguezi affected by sewage discharge.

Diseño de muestreo en los bancos intermareales del bivalvo mitílido Brachidontes rodriguezi afectados por descargas cloacales. 
The material examined was collected from 1- station $\mathrm{X}\left(37^{\circ} 50.860 \mathrm{~S}-57^{\circ} 27.315 \mathrm{~W}, 150\right.$ specimens from 8 sampling units), 2- stations A (33 specimens), B (70) and $\mathrm{C}$ (39), placed around the intertidal effluent $\left(37^{\circ}\right.$ $55.591 \mathrm{~S}-57^{\circ} 31.701 \mathrm{~W}$ ); 3- sampling units (also 78 $\mathrm{cm}^{2}$ corers) in vertical artificial substrates of centric beaches of Mar del Plata (Scelzo et al. 1996), 24 specimens (Fig. 1).

\section{Results and Discussion}

The material examined fits well with the description of Hartmann-Schröeder (1962a): Protoaricinae (first two segments achaetous), branchiae from the third setiger, all thoracic notosetae are crenulate capillaries, acicular setae present in posterior notopodia. In our material, notosetae include thick hooks with three to five teeth. The description of specimens from Chile (HartmannSchröeder 1962b) shows hooks with only three teeth. Other remarkable features are: prostomium pointed in many specimens, posterior end in some individuals shows an elongate morphology. The number of setigers varies from 45 to 78 in 3,5 to $14 \mathrm{~mm}$ long, in specimens from Mar del Plata (Fig. 2).

Protoariciella uncinata has been found in interticial sediments accumulated between mussel beds of Brachidontes rodriguezi. These sediments are poorly

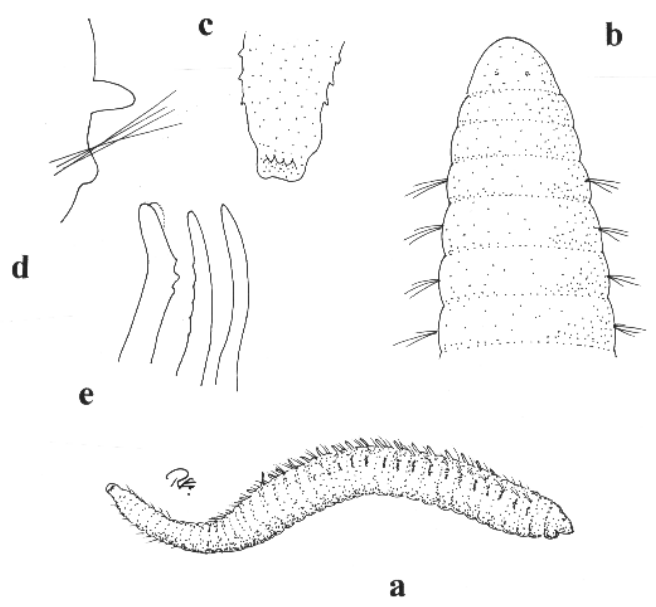

Figure 2

Protoariciella uncinata. a: General view; b: anterior end, in dorsal view; c: posterior end, in ventral view; d: median parapodia; e: uncini. b-e redrawn from the original description.

Protoariciella uncinata. a: vista general; b: parte anterior, en vista dorsal; c: parte posterior, en vista ventral; d: parapodio medio; e: uncini. b-e: redibujado de la descripción original. sorted, being a mixture of sand grains (fine to coarse) with shell debris. In abrassion platforms intersticial sediments can reach up to $100 \mathrm{~kg} \mathrm{~m}^{-2}$ (Fig. 3), in a thick layer placed between mussels and substrate. Organic matter content of sediments varies along a gradient from effluent (Fig. 4).

The distribution of Protoariciella uncinata shows a negative effect due to organic pollution, being mean density lower in impacted areas (Stations E to A), rather than in control sites (Station X) (Fig. 5). The species was also found in vertical artificial substrates (breakwaters) of central Mar del Plata beaches, in high and middle levels of the intertidal (Scelzo et al. 1996).

Around Lima Department $\left(10^{\circ} 45^{\prime} \mathrm{S}-12^{\circ} 57^{\prime} \mathrm{S}\right.$, on the Pacific coast of Peru), Protoariciella uncinata is a frequent species associated to mussel beds of the mytilid Perumytilus purpuratus (Lamark, 1819) (see Paredes \& Tarazona 1980). In central Chile $P$. uncinata is known to be indicator of organically enriched sediments (Cañete, com. pers.).

In this part of the southwestern Atlantic shore, the indicator species are Capitella capitata and Boccardia polybranchia, which show a 'classical' behaviour as indicators of organic pollution (Elias et al. 1999), being dominant or subdominant in impacted areas (stations $\mathrm{E}$ and $\mathrm{C}$ ).

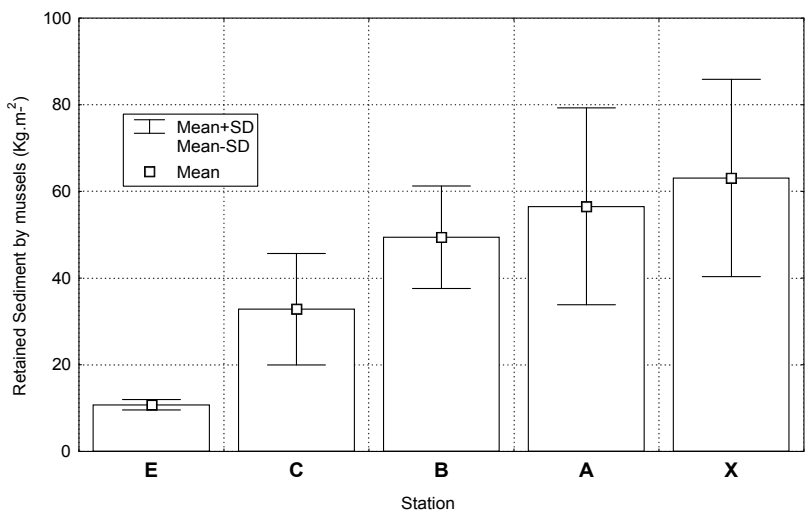

Figure 3

Sediments accumulated $\left(\mathrm{kg} \mathrm{m}^{-2}\right)$ between intertidal epilitic mytilids. The area is an abrassion platform affected by sewage.

Sedimentos acumulados $\left(\mathrm{kg} \mathrm{m}^{-2}\right)$ entre los mitílidos epilíticos intermareales. El área es una plataforma de abrasión afectada por descargas cloacales. 


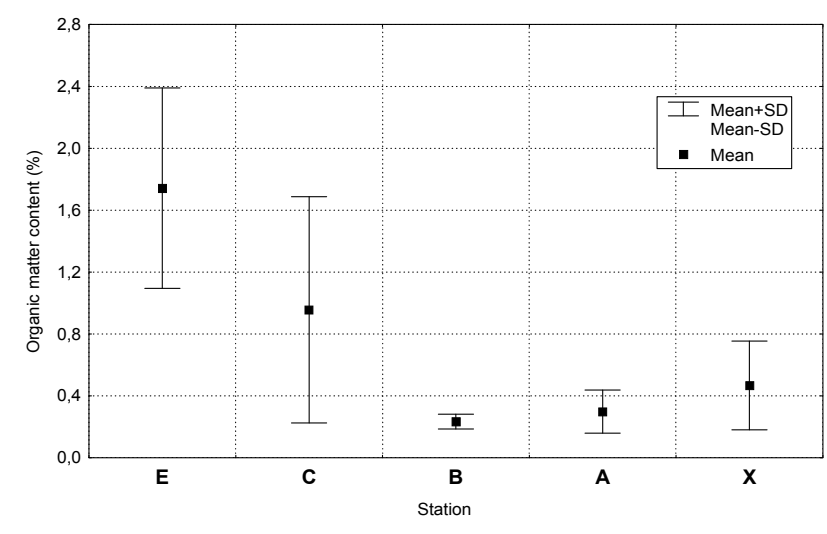

Figure 4

Organic matter content (\%) of sediments. Stations $E$ to $A$ are affected by sewage, while station $X$ is a control site $9 \mathrm{~km}$ north to the effluent.

Contenido de materia orgánica (\%) de los sedimentos. Las estaciones E - A son afectadas por descargas cloacales, mientras que la estación X es un sitio control ubicado $9 \mathrm{~km}$ al norte del efluente.

\section{References}

Hartmann-Schröeder G. 1962a. Zweiter Beitrag zur Polychaetenfauna von Peru. Kieler Meeresforschungen 18: 109-147.

Hartmann-Schröeder G. 1962b. Die Polychaeten des Eulittorals. Zur Kenntnis des Eulittorals der chilenischen Pazifikkuste und der argenistchen Kust Sudpatagoniens unter besonderer Berucksichtigung der Polychaeten und Ostracoden. Mitteilungen aus dem Hamburgischen Zoologischen Museum und Institut, Ergänzungsband zu Band 60 (Suppl. Vol.): 57-167.

Jacobi CM. 1987. The invertebrate fauna associated with intertidal beds of the brown mussel Perna perna (L.) from Santos, Brazil. Studies in Neotropical Fauna and Environment, 22: 57-72.

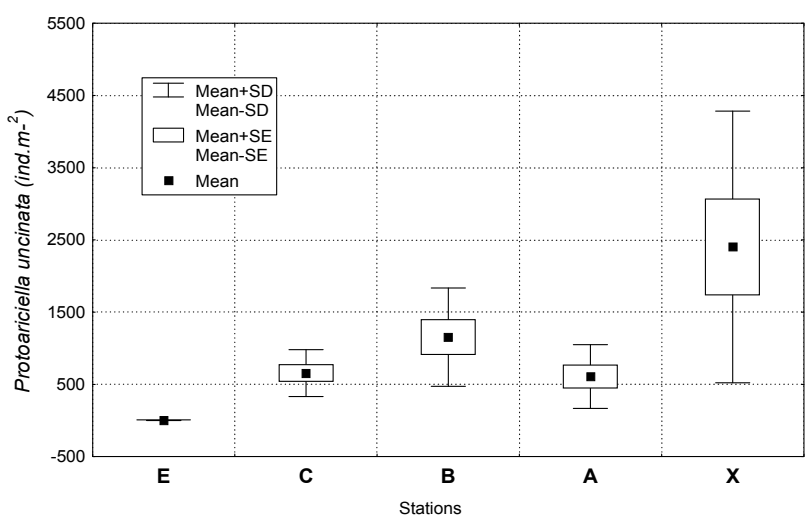

Figure 5

Density (ind $\mathrm{m}^{-2}$ ) of Protoariciella uncinata in intertidal mussel beds of Brachidontes rodriguezi developed in abrassion platforms affected by sewage.

Densidad (ind $\mathrm{m}^{-2}$ ) de Protoariciella uncinata en bancos de bivalvos intermareales de Brachidontes rodriguezi desarrollados sobre plataformas de abrasión afectadas por descargas cloacales.

Olivier SR, A Escofet, JM Orensanz, SE Pezzani, AM Turro \& ME Turro. 1966. Contribución al conocimiento de las comunidades bénticas de Mar del Plata. I. El litoral rocoso entre Playa Grande y Playa Chica. Anales de la Comisión de Investigaciones Científicas de la Provincia de Buenos Aires 7: 185-206.

Penchaszadeh P. 1973. Ecología de la comunidad del mejillín (Brachidontes rodriguezi, D’Orb.) en el mediolitoral rocoso de Mar del Plata (Argentina): el proceso de recolonización. Physis A, 32 (84): 51-64.

Scelzo MA, R Elias, EA Vallarino, M Charrier, N Lucero \& F Alvarez. 1996. Variación estacional de la estructura comunitaria del bivalvo intermareal Brachidontes rodriguezi (Dórbigny, 1846) en sustratos artificiales (Mar del Plata, Argentina). Neritica 10: 87-102. 